\title{
Seismic evidence of the active regional tectonic faults and the Copahue volcano, at Caviahue Caldera, Argentina
}

\author{
V. M. Montenegro ${ }^{1} \cdot$ S. Spagnotto ${ }^{2,3} \cdot$ D. Legrand ${ }^{4}$ (D) A. T. Caselli ${ }^{1,2}$ \\ Received: 5 October 2020 / Accepted: 8 February 2021 \\ (C) International Association of Volcanology \& Chemistry of the Earth's Interior 2021
}

\begin{abstract}
Understanding interactions between tectonic faults and a nearby active volcano is often realized by combining seismic and field observations. A good example of such an interaction is the Caviahue caldera. It is located in an intra-arc extensional pull-apart basin, within a transition zone joining the northern part of the right-lateral strike-slip Liquiñe-Ofqui Fault System and the thrustfault Antiñir-Copahue fault zone. Most of the active volcanoes in South Chile are related to the Liquiñe-Ofqui Fault System. Some faults located inside the Caviahue caldera were described with reverse mechanisms by some studies whereas they were found to be normal by others. In order to discriminate the actual focal mechanisms, two seismic clusters that occurred in 2017 and 2018 inside the Caviahue rectangular caldera, close to the active Copahue volcano, were studied. Earthquakes (520) were located; focal mechanisms (56) were determined from which an average seismic moment tensor was calculated. The locations and focal mechanisms of the earthquakes allow splitting the seismicity into two main regions, one of tectonic origin (with strike-slip faults) and another one of volcanic origin (with normal faults). The first seismic cluster is located close to Caviahue village, with strikeslip focal mechanisms, in an NNE direction as the nearby Liquiñe-Ofqui Fault strikes. The other part of the seismicity is located close to the northeastern structures of Copahue volcano, in the hydrothermal zone of Anfiteatro, Termas de Copahue, and Maquinitas. It is oriented in an NE direction and is composed of earthquakes with normal focal mechanisms, not reverse as postulated in past studies. The active Copahue volcano lies in the SW prolongation of these normal faults, in agreement with the tectonics of the Caviahue caldera. Then, the two nearby seismic clusters reveal both a tectonic origin, with strike-slip focal mechanisms compatible with the Liquiñe-Ofqui Fault System, and a hydrothermal origin with normal focal mechanisms, compatible with the hydrothermal system of the Copahue active volcano.
\end{abstract}

Keywords Liquiñe-Ofqui Fault System $\cdot$ Caviahue caldera $\cdot$ Copahue volcano $\cdot$ Antiñir-Copahue Fault zone

\section{Introduction}

Understanding the interactions between crustal faults and volcanism is important to monitor active volcanoes and to find

Editorial responsibility: A. Cannata

D. Legrand

denis@geofisica.unam.mx

1 Universidad Nacional de Río Negro, Instituto de Investigación en Paleobiología y Geología, Río Negro, Argentina

2 Consejo Nacional de Investigaciones Científicas y Técnicas, CONICET, Buenos Aires, Argentina

3 Universidad Nacional de San Luis, Ejército de los Andes, 950 San Luis, Argentina

4 Universidad Nacional Autónoma de México, Instituto de Geofísica, Unidad Michoacán, Morelia, Mexico geothermal resources. Most of the volcanoes of the Southern Andean Volcanic Zone (33.3-46 $\mathrm{S}$ ) are aligned in the same $\mathrm{NE}$ direction as the faults of the Liquiñe-Ofqui Fault System (LOFS, Fig. 1), favoring the path of fluids as magma (Cembrano and Lara 2009). As an example, circulation of crustal fluids at shallow depths in the brittle highly fractured crust has been imaged using magnetotellurics at the LOFS, near the Osorno volcano (Díaz et al. 2020). When fluids migrate until the surface through crustal faults (Cox 2005; Gudmundsson 2011; Pérez-Estay et al. 2020), they can generate a very specific seismicity, different from the more classical tectonic seismicity located at the interplate contact in a subduction zone. Studying this seismicity allows following the dynamics of these faults as well as monitor active volcanoes, especially to detect a possible volcanic unrest using volcano-tectonic earthquakes (VTs) as an early warning alert system (White and McCausland 2019). For example, the temporal migration of distal VTs (sometimes located until 15-20 

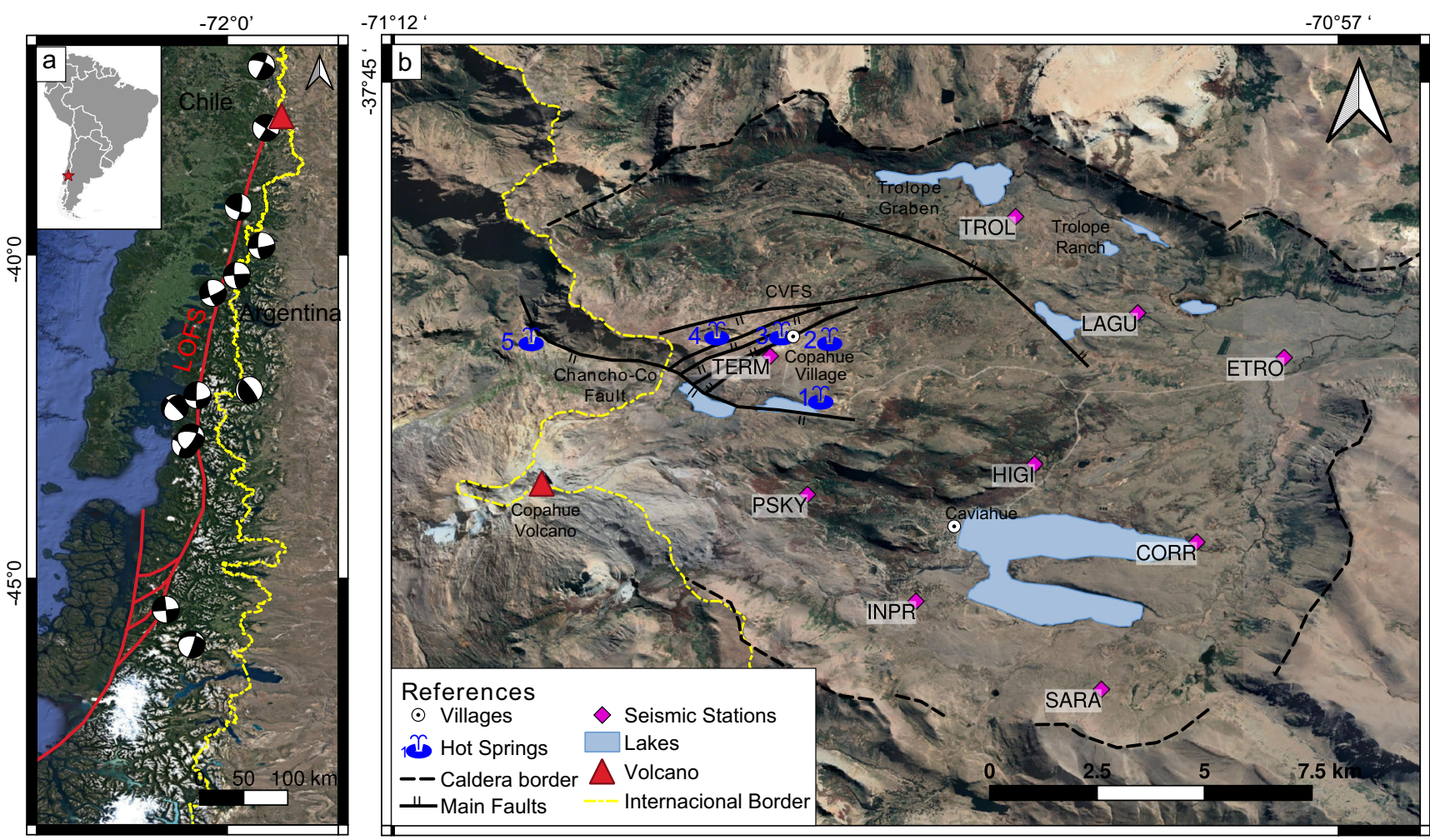

Fig. 1: (a) Geodynamic context of South America. The Liquiñe-Ofqui Fault System (LOFS) is represented by a red line. Focal mechanisms were taken from G-CMT catalog, for earthquakes of depth less than $40 \mathrm{~km}$ and from 1976 to 2020. Red star represents Copahue volcano. (b) Zoom of the Caviahue caldera with the hot springs: (1) Las Máquinas, (2) Termas de
Copahue, (3) Las Maquinitas, (4) Anfiteatro, and (5) Chancho-Co. Red triangle is the Copahue volcano. The seismic stations installed in 2017 2018 are represented with green diamonds. Geological faults were redrawn from Barcelona et al. (2019). Image source for the background is from Google Earth, earth.google.com/web $\mathrm{km}$ from the volcano) towards an active volcano can be a sign of its unrest as already observed at many volcanoes (see White and McCausland 2016, 2019, for a compilation). Even if VTs have been located at many volcanoes, only a few studies have determined their focal mechanism, allowing discriminating when VTs are related to local faults or to the hydrothermal and/or volcanic activity. Seismic studies realized along the LOFS are rare, mainly for logistic reasons in these remote regions (Ibáñez et al. 2008; Lange et al. 2008; Mora-Stock et al. 2010; Legrand et al. 2011; Russo et al. 2011; Agurto et al. 2012; Vargas et al. 2013; Kanamori and Rivera 2017; Sielfeld et al. 2019; Pérez-Estay et al. 2020).

VTs often appear as seismic swarms which are composed of similarly sized earthquakes that occur in a relatively small volume and in a relatively small-time window (Mogi 1963). Some of them are tectonic in origin (Mogi 1963; Legrand et al. 2005,2020 ), and many of them are volcanic in origin, for example, related to magma motions (Hill 1977; Endo et al. 1981; Hill et al. 1990; Power et al. 1994; McNutt 1996; Hurst and McGinty 1999). Usually, the magma does not reach the surface (e.g., Hill 1977; Hill et al. 1990; Amato et al. 1994; Aoki et al. 1999; Roman et al. 2004). A case of particular interest is the interactions between tectonic faults and a nearby active volcano generating seismic swarms or clusters of earthquakes which may have both, a tectonic and a volcanic origin, as it is the case in the southern part of the LOFS (Legrand et al. 2011, Fig. 1). Distinguishing the actual origin of seismic swarms helps in eruption forecasting (White and McCausland 2019). VTs are often the response of magma transport, revealing interactions between fluids (gas, magma, and/or water) and the solid ground (Chouet 1996; Chouet and Matoza 2013). During the magma migration, the local stress field can be modified and significantly differ from the regional stress tensor (Legrand et al. 2002). VTs can be related to a nearby active volcano, to pressure changes due to volcanic and hydrothermal fluids (Ibáñez et al. 2000, 2003) and also to the local tectonics (Walter et al. 2007). Spatial distribution of VTs is an efficient tool to constrain the geometry of reservoirs and also to monitor magma migration (Toda et al. 2002). VTs can be used to perform velocity tomography and reveal magma chambers (Patanè et al. 2003). VTs often precede eruptions or magma intrusions, making them an efficient tool to forecast eruptions, especially for long-dormant volcanoes (see White and McCausland 2019 for a compilation). These VTs often start on tectonic faults located until about $30 \mathrm{~km}$ from the future potential eruption and rarely beneath the volcano itself (White and McCausland 2019). Nevertheless, the presence of VTs on a volcano is not systematically related to 
the activity of the volcano. Some eruptions occurred with almost no VTs, and the presence of many VTs are not systematically related to an eruption, as for example, at Volcan Cosiguina, Nicaragua (White and McCausland 2016), with a small intrusion, or the 2005 VT swarm following the 2004 Sumatra-Andaman $M_{\mathrm{w}} 9.2$ earthquake (Kundu et al. 2012): in these cases, the intrusion was too small to reach the surface and generate an eruption.

Seismic clusters and swarms regularly occur along the LOFS, better seen and identified when a local seismic network has been installed (Ibáñez et al. 2008; Lange et al. 2008). Knowing their tectonic or volcanic/ geothermal origin helps understanding the link between faults and volcanism. As an example, the 2007 Aysen swarm located in the southern part of the LOFS (Legrand et al. 2011; Agurto et al. 2012) was the manifestation of a strong interaction between local faults and local monogenetic volcanoes, even if in this case the magma did not reach the surface. VTs were already observed at Caviahue caldera before the present study. For example, Ibáñez et al. (2008) detected two clusters of VTs that occurred during a quiescence period of the volcano (from November 2003 to May 2004 and from November 2004 to April 2005), using a seismic antenna of six short-period seismometers $(1 \mathrm{~Hz})$. They could locate 73 VTs during these two periods. One cluster was located along the border of the Caviahue Lake, at shallow depths (from 0.6 to $2.8 \mathrm{~km}$ below the surface). Another one was located $15 \mathrm{~km}$ south of the caldera border, at depth of about $4 \mathrm{~km}$. These authors proposed that this cluster was related to a hydrothermal activity, due to the presence of nearby fumarolic manifestations and associated the VTs to the presence of hydrothermal fluids, reducing the effective normal stress of preexisting faults, rather than with the activity of Copahue volcano, which is far away from the cluster (about $15 \mathrm{~km}$ ).

Our study shows the results of a field experiment realized at Caviahue caldera, near the active Copahue volcano, Argentina. Copahue volcano is one of the most active volcanoes of Argentina, located between the Central and Patagonian Andes, close (less than $3 \mathrm{~km}$ ) to the touristic village of Copahue, and its thermal baths and a ski resort. The village of Caviahue is also close, located at $8 \mathrm{~km}$ from the volcano. Hence, monitoring the background activity of this volcano in such a touristic region is crucial. We installed a local seismic network composed of eight broadband seismometers. We determine the background level of distal VTs, which is fundamental to forecast an eventual eruption, as seen for other volcanoes (White and McCausland 2016). We could locate these VTs with a high precision, determine their focal mechanisms, and discriminate between their tectonic or hydrothermal and/or volcanic origin, as well as solve the controversy between normal or reverse focal mechanism of some local faults. The results reveal that a part of the seismicity has a tectonic origin, related to the nearby LOFS, whereas the other part of the seismicity has a hydrothermal origin, related to the active Copahue volcano and fluid paths through the LOFS.

\section{Geological and tectonic setting}

The oceanic Nazca plate is subducting under the continental South American plate with a velocity varying from 8 $\mathrm{cm} /$ year at the Northern part of Chile to $6.6 \mathrm{~cm} /$ year at the Southern part, close to the triple junction point with the Antarctic plate (DeMets et al. 1994; Angermann et al. 1999). The direction of convergence between the Nazca and South American plates is oblique in the southern part of the contact, resulting in partitioning of the deformation. One part of the deformation is located at the trench, generating large thrust earthquakes. Another part of the deformation is expressed by the LOFS, a right-lateral strikeslip fault system, generating a shallower crustal seismicity of smaller magnitudes than the thrust earthquakes (Barrientos and Ward 1990; Cembrano et al. 1996; Lavenu and Cembrano 1999; Watt et al. 2009).

The LOFS is the longest strike-slip fault system in South Chile-Argentina (Fig. 1). It is more than $1200 \mathrm{~km}$ long, and it is composed of parallel right-lateral strike-slip faults generating several pull-apart systems (Cembrano et al. 1996; Folguera et al. 2002; Adriasola et al. 2006; Rosenau et al. 2006; Cembrano and Lara 2009). These right-lateral strikeslip faults have been directly observed at the surface by geologists, but only south of $38^{\circ} \mathrm{S}$ (Cembrano et al. 1996, 2002; Cembrano and Lara 2009). Other strike-slip faults have been inferred between $34^{\circ} \mathrm{S}$ and $46^{\circ} \mathrm{S}$ using focal mechanisms of earthquakes (Chinn and Isacks 1983; Lange et al. 2008). The LOFS plays a fundamental role in controlling the magmatic activity along the volcanic front (Lavenu and Cembrano 1999; Rosenau 2004). Most of active polygenetic volcanoes and instinct monogenetic volcanoes in Chile-Argentina lie on the LOFS or inside extensional regions and 'rectangular' caldera, such as the Caviahue caldera (Cembrano et al. 1996, 2002; Stern 2004; Radic 2010).

The Caviahue caldera (also known as Agrio caldera) is located at the northern extremity of the right-lateral strikeslip LOFS and at the southern extremity of the thrust-fold Antiñir-Copahue Fault System (Cembrano et al. 1996, 2002; Folguera and Ramos 2000; Folguera et al. 2004, 2016; Stern 2004; Melnick et al. 2006; Radic 2010). It is a rectangular intra-arc pull-apart basin $\left(20 \times 15 \mathrm{~km}^{2}\right)$, of about $2 \mathrm{Ma}$, older than the regional volcanoes, such as the quaternary (0.8-1.2 Ma) Copahue volcano (Pesce 1989; Folguera et al. 2016). Its formation is controlled by both the regional stress field of the convergence of 
Nazca and South American plates and the local stress field due to the LOFS (Melnick et al. 2006). The Caviahue caldera is mainly composed of (1) the active andesitic to basaltic-andesite strato-volcano Copahue (about 3000 m.a.s.1.) located at the western rim of the Caviahue caldera (Hildreth and Moorbath 1988; Linares et al. 1999); (2) an intense geothermal field inside the Caviahue caldera; and (3) an active regional and local complicated fault system. These three aspects (volcanic, tectonic, and hydrothermal) closely interact in a complex way (Bonali et al. 2016). As an example, the $M_{\mathrm{w}} 8.8$ February 27, 2010, Maule thrust subduction earthquake may have changed the seismic and volcanic activity of Copahue volcano from July to December 2012 (Forte et al. 2012; Bonali 2013; Caselli et al. 2016).

The Caviahue caldera hosts a hydrothermal system, with large gas discharges. Geophysical studies showed the existence of two hydrothermal reservoirs, located at $800-1000 \mathrm{~m}$ and $1400 \mathrm{~m}$ depth, respectively (Tamburello et al. 2015, and references within). As a reference, Copahue village is at 1000 $\mathrm{m}$ of altitude. Five geothermal fields have been identified, with fumaroles (of temperatures up to $135^{\circ} \mathrm{C}$ ), boiling and bubbling water and mud pools, with temperatures up to $96^{\circ} \mathrm{C}$ (Agusto et al. 2007). These five fields are Las Máquinas, Las Maquinitas, Termas de Copahue, Anfiteatro, and Chancho-Co (Fig. 1). These thermal areas are located northeast of the Copahue volcano (Varekamp et al. 2001). The origin of the water is mainly meteoric, except at Chancho-Co which presents a more volcano-hydrothermal origin, due to the proximity of the Copahue volcano (Vélez et al. 2011). Many active faults are present in this region, which favors the ascent of hot fluids close to the surface and the presence of hot springs.

The neotectonics of the region has been described in the past, sometimes with contradictory observations and interpretations. Some of the main structures of the Caviahue caldera described by Bonali et al. (2016) are (Fig. 1) (a) normal faults located at the borders of the caldera, trending in WNW and NNE directions; (b) right-lateral strike-slip faults trending in an NNE direction, located at the SW part of the Copahue volcano, corresponding to the northern edge of the LOFS; (c) left-lateral strike-slip faults trending in an NW direction, and (d) NE-trending faults, controlling the geothermal area, located in the NE portion of Copahue volcano. They are called the Copahue Village Fault System (CVFS). The focal mechanisms of these faults are not well defined, and contradictory interpretations exist. Melnick et al. (2006), Folguera et al. (2004), and Rojas Vera et al. (2009) inferred that they are reverse faults with a small right-lateral component, due to the local transpressional stress-tensor. On the other hand, Bonali et al. (2016) and Lundgren et al. (2017) concluded that these faults are normal, with a small right-lateral strike-slip component, using different approaches such as aerial photos, field observations, and InSAR data.

\section{Data and methodology}

\section{The temporary seismic network}

A temporary network composed of eight broadband seismometers was installed in the center of the Caviahue caldera from December 01, 2017, to March 30, 2018 (Fig. 1). Its characteristics are described in Supplementary Material, as well as some data, to appreciate their quality).

\section{Earthquake locations}

The earthquakes located in this study have clear $\mathrm{P}$ and $\mathrm{S}$ waves and were determined to be volcano-tectonic earthquakes (VTs). Fig. 2 shows the time distribution of seismicity with associated duration magnitudes (we mention later how they were calculated). Before locating the VTs, we checked the quality of the arrival times of the $\mathrm{P}$ and $\mathrm{S}$ waves. One way of doing this is to perform the generalized Wadati method (i.e., calculating the double-differences of $\mathrm{P}$ and $\mathrm{S}$ waves, Legrand et al. 2021). Bad readings are detected when points deviate too much from the line describing these doubledifferences and are corrected (Fig. 3). We calculated the corresponding $\mathrm{Vp} / \mathrm{Vs}$ ratio of 1.69 (Fig. 3), where $\mathrm{Vp}$ and $\mathrm{Vs}$ are the $\mathrm{P}$-wave and $\mathrm{S}$-wave velocities, respectively. This ratio was calculated using only earthquakes with four or more stations and was used in our velocity model. After this test, the earthquakes have been located. A seismic sequence of hundreds of earthquakes began 2 days after the installation of the network, among which 520 could be located within the network (Fig. 4). The earthquakes were manually identified and cut. Afterwards, the $\mathrm{P}$ and $\mathrm{S}$ arrival times were manually read. They were located using the HYPO_DD software (Waldhauser and Ellsworth 2000). The choice of a velocity model to locate earthquakes on a volcano is always critical because in many cases it is unknown. What is classically done is to use a model determined on another volcano. For example, for Caviahue caldera, Ibáñez et al. (2008) used the velocity model determined for Deception Island volcano. We used this model and found a median rms error of $0.8 \mathrm{~s}$. To partially help in the choice of a velocity model, Lesage et al. (2018) did a compilation of velocity models on many kinds of volcanoes and propose a 'typical' one for different categories of volcanoes. They showed seismic velocities change significantly in the first kilometer for andesitic basaltic volcanoes whereas they are almost constant for caldera volcanoes. As Caviahue is a caldera, we tried a second velocity model composed of four horizontal layers with a constant velocity in the first kilometer (Malone and Pavlis 1983; Pavlis and Booker 1983). The median rms error with this model was $0.11 \mathrm{~s}$, much smaller than the previous one of $0.8 \mathrm{~s}$. As a consequence, we decided to use this simple model. 


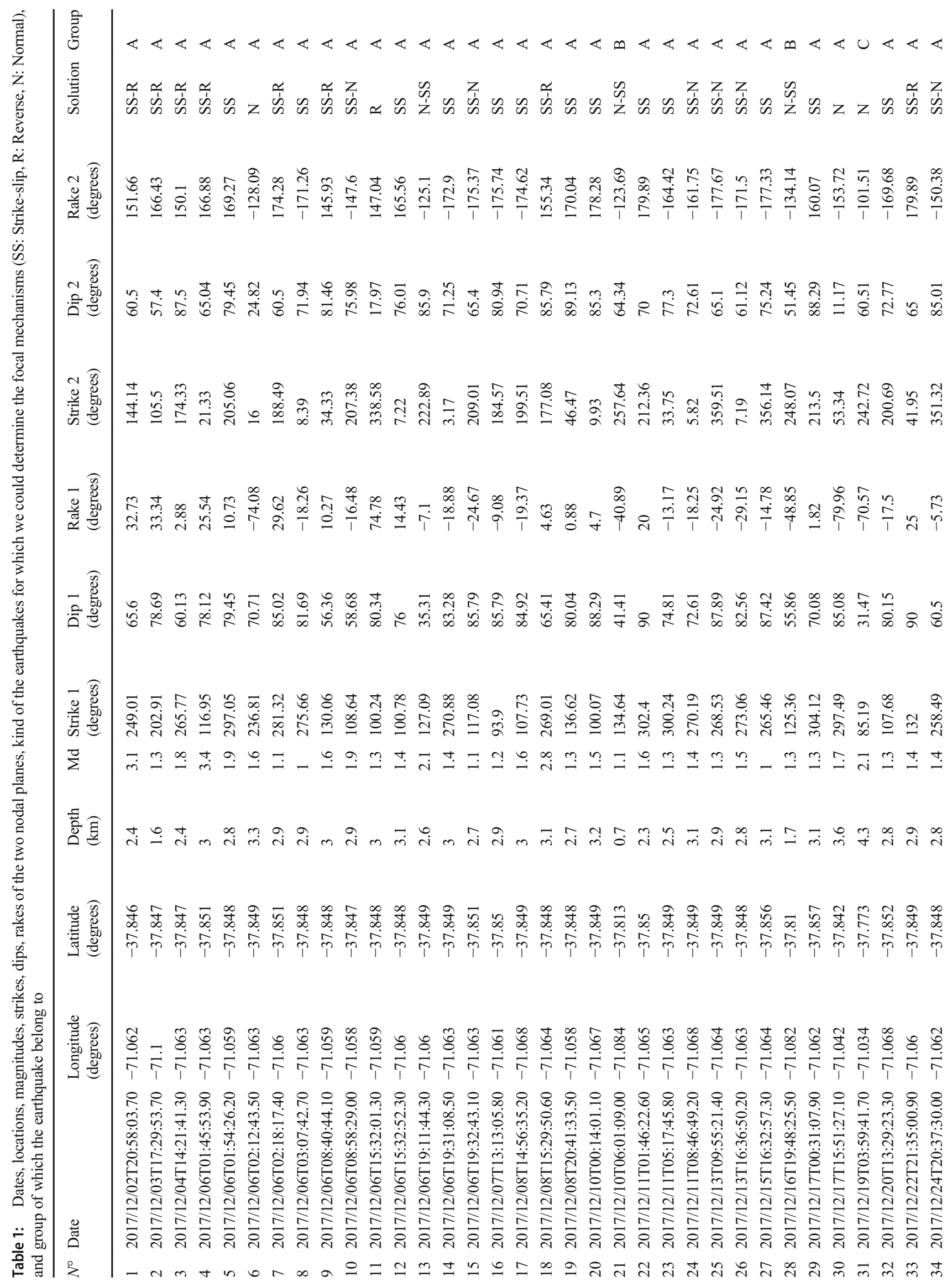




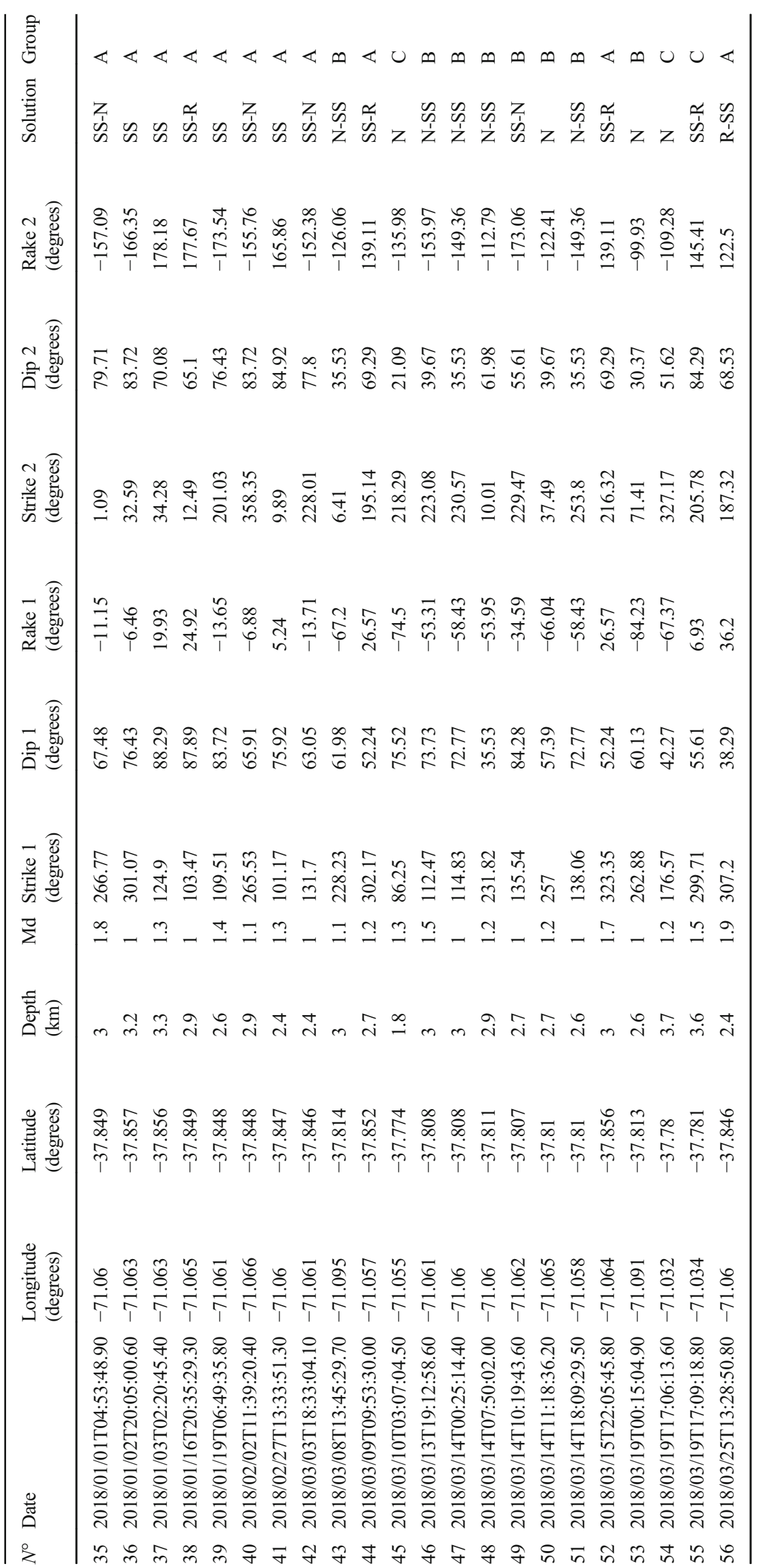




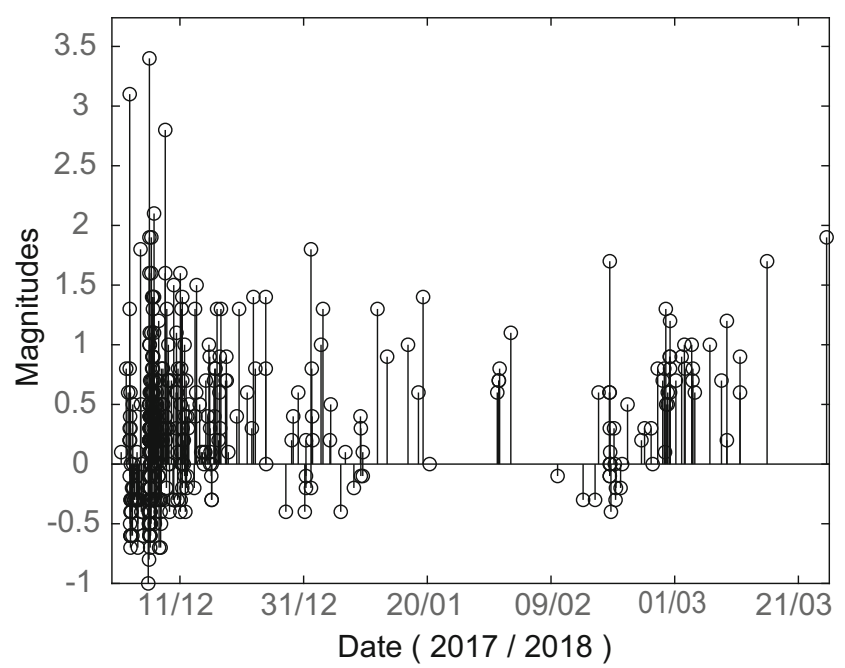

Fig. 2. Temporal distribution of the earthquakes with associated magnitudes Md

The zero level for depths corresponds to sea level. Positive depths correspond to depths below sea level, whereas negative values correspond to altitudes above sea level (in practice we have not such seismicity).

\section{Focal mechanisms}

Double-couple focal mechanisms were determined for 56 VTs, using both, the first-motion P-wave polarities, and when possible the $\mathrm{S} / \mathrm{P}$ amplitude ratios. The two softwares FOCMEC (Snoke 1984) and HASH (Hardebeck and Shearer 2003) included in the SEISAN package (Havskov

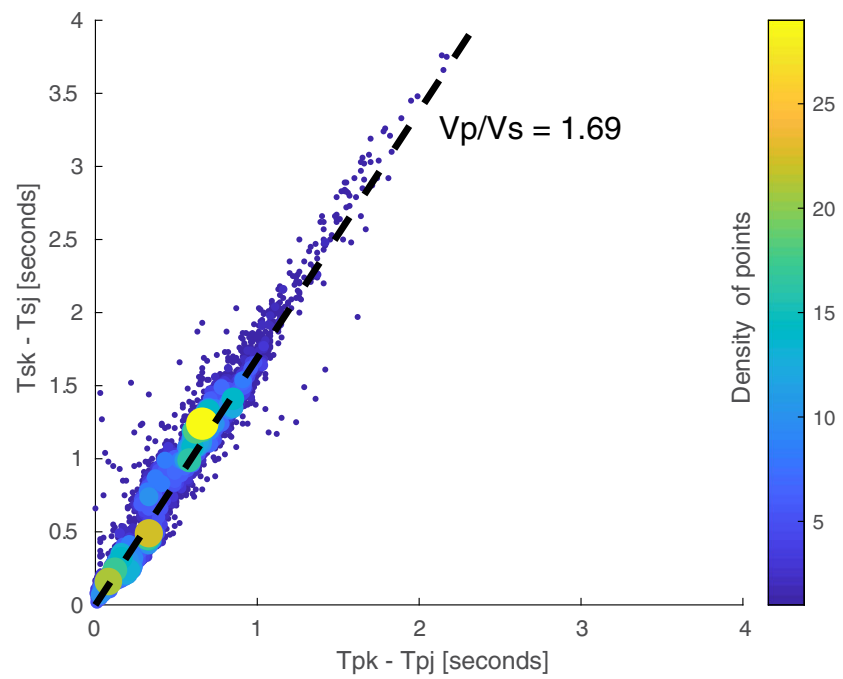

Fig. 3. The generalized Wadati diagram. Vp and Vs are the P- and Swave velocities, respectively. Tpj and Tpk are arrival times of $\mathrm{P}$ wave at station number $\mathrm{j}$ and $\mathrm{k}$, respectively. Tsj and Tsk are arrival times of $\mathrm{S}$ wave at station number $\mathrm{j}$ and $\mathrm{k}$, respectively. The slope gives the $\mathrm{Vp} / \mathrm{Vs}$ ratio of 1.69 et al. 2020) were used. The results obtained with FOCMEC and HASH were very similar, so only those obtained with FOCMEC are shown and listed in Supplementary Material. For each focal mechanism, the corresponding seismic moment tensor was calculated, and the summation (with its corresponding $\mathrm{P}$ and $\mathrm{T}$ axes) of these seismic moment tensors was performed using FaultKin 8 (Allmendinger et al. 2011).

\section{Results}

\section{Locations}

Figure 4 shows the spatial distribution of the 520 VTs that could be located. They are spatially well separated, and we split them into three distinct regions, defining three groups (that we called A, B, and C) of earthquakes. The first group " $A$ " is composed of VTs located in the vicinity of Caviahue, northwest of Caviahue Lake. It has the largest number of earthquakes (474). The seismicity of this group contains the two largest VTs (yellow points in Fig. 4 and events one and four, respectively, in Supplementary Material) that occurred on December 2 and December 6, 2017. They have duration magnitudes $M_{\mathrm{d}}$ of 3.1 and 3.4 and depths of $2 \mathrm{~km}$ and $4.5 \mathrm{~km}$, respectively. They were felt by the population of Caviahue. The second group " $\mathrm{B}$ " is composed of $37 \mathrm{VTs}$ located near the village of Copahue, of duration magnitudes between 0 and 1.5, and depths varying between 0.7 and $3.1 \mathrm{~km}$. The third small group "C" is composed of nine isolated VTs located in the northern border of the Caviahue Caldera, in the ranch of Trolope, of $M_{\mathrm{d}}<2.1$, and depths varying between 1.0 and $4.3 \mathrm{~km}$.

The NS, EW, and vertical median location errors of these VTs are $0.6 \mathrm{~km}, 0.8 \mathrm{~km}$, and $1.4 \mathrm{~km}$, respectively (Fig. $5 \mathrm{a}-\mathrm{c}$ ). The median number of stations used is eight (Fig. 5d). The median average gap is $73^{\circ}$ (Fig. 5e). The small location errors (median error of $0.11 \mathrm{sec}$ in the rms, Fig. 5f) are due to several factors. Firstly, the stations are very close to the VTs, generating small ts-tp arrival time differences between $\mathrm{P}$ and $\mathrm{S}$ waves and therefore small errors on locations. Secondly, the stations are well distributed around the seismic sequence, as revealed by the small gap angle of $73^{\circ}$. This will help selecting the rupture fault plane among the two nodal planes (see paragraph 4).

\section{Gutenberg-Richter law}

As a local absolute magnitude calibration is not available for Copahue area, we used the duration magnitudes $M_{\mathrm{d}}$ introduced by Lee et al. (1972), using the modified formula $M_{\mathrm{d}}=$ $-2.46+2.82 \log _{10}(\mathrm{~d})$ where $\mathrm{d}$ is the earthquake duration. The resulting magnitude is the average of all the magnitudes 


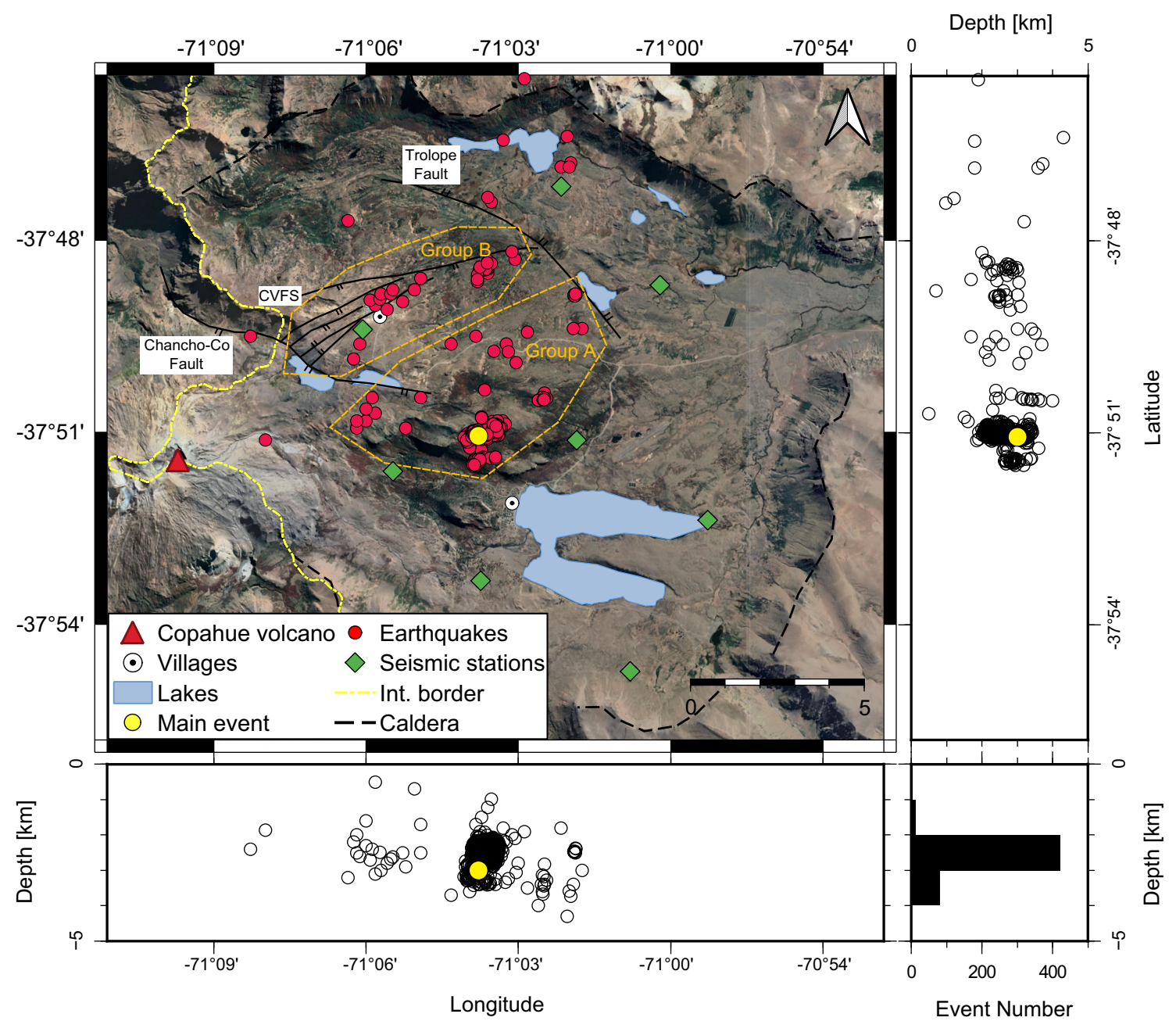

Fig. 4: Caviahue Caldera with the main local structures, modified from Bonali et al. (2016). The earthquakes plotted are located with Hypo-DD. Yellow circle represents the earthquake of December 6, $2017\left(\mathrm{M}_{\mathrm{d}}=3.4\right)$. Image source for the background is from Google Earth, earth.google.com/web

at all the stations. For comparison, if we use the one of Ibáñez et al. (2008) for Copahue volcano, $M_{\mathrm{d}}=-2.70+$ $2.80 \log _{10}(\mathrm{~d})$, who took the one of another volcano (Deception Island), we have magnitudes about 0.3 smaller. The $b$ value calculated with our definition of magnitudes is 1.50 whereas it is 1.26 if we use the magnitudes using the Ibáñez et al. (2008) formula. In both cases, our interpretation will not change because the two $b$ values are much larger than unity. The $b$ value of the Gutenberg-Richter law was calculated using the maximum likelihood method (Aki 1965). The $b$ value could only be calculated for Group A which has enough VTs to do it (Fig. 6). We found $b=1.50$ \pm 0.15 for a completeness magnitude of 1.3.

We have to mention that our seismicity is very concentrated in space and time, so the $b$ value corresponds only to this small region and a small-time interval. For this reason, the interest of such value may be very limited. But for the sake of completeness of the study, we decided to add this information, showing the role of fluids in the magnitude distribution of earthquakes.

\section{Focal mechanisms}

A strong trade-off exists between locations and focal mechanisms, especially for local seismicity. As mentioned before, we tested two different velocity models and took the one with the corresponding smaller rms median error of $0.11 \mathrm{~s}$ (Fig. $5 \mathrm{f}$ ). The corresponding errors on locations were about $0.7 \mathrm{~km}$ on epicenters and $1.4 \mathrm{~km}$ on vertical components (Fig. 5a-c), small enough not to change significantly the focal mechanisms.

The double-couple focal mechanisms are listed in Table 1, plotted in Fig. 7, and are classified for the three Groups A, B, and $\mathrm{C}$ in Fig. 8. Group A is mainly composed of strike-slip mechanisms (Figs. 7 and 8). In particular, the couple of the three angles (strike, dip, rake) of the focal mechanisms of the two largest VTs (Table 1, events one and four) is $249^{\circ} / 66^{\circ} / 33^{\circ}$ 
Fig. 5: Histograms of the location errors of earthquakes in the (a) NS, (b) EW, and (c) vertical directions. The median error is 0.6 $\mathrm{km}, 0.8 \mathrm{~km}$, and $1.4 \mathrm{~km}$, respectively. (d) Histogram of the number of seismic stations used to locate earthquakes. The median value of the number of stations is 8. (e) Histogram of the gap angle station distribution. The median value is $73^{\circ}$. (f) Histogram of the RMS errors of the earthquake locations. The median value is 0.11 $\mathrm{s}$ of earthquakes with respect to
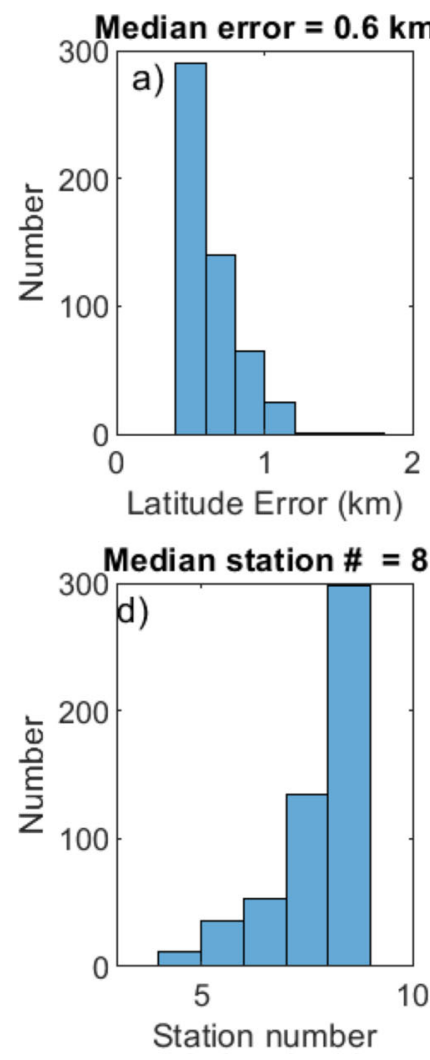

and $144^{\circ} / 61^{\circ} / 152^{\circ}$ for event one $\left(M_{\mathrm{d}}=3.1\right)$ and $117^{\circ} / 78^{\circ} / 26^{\circ}$ and $21^{\circ} / 65^{\circ} / 167^{\circ}$ for event four $\left(M_{\mathrm{d}}=3.4\right)$. Focal mechanisms of Groups B and C are mainly normal faults (Figs. 7 and 9).

The average seismic moment tensor obtained for Group A indicates a strike-slip focal mechanism with the $P$-axis in the NE-SW $\left(242^{\circ}\right)$ direction and the $T$-axis in the NNW-SSE $\left(333^{\circ}\right)$ direction. The average moment tensor for Group B

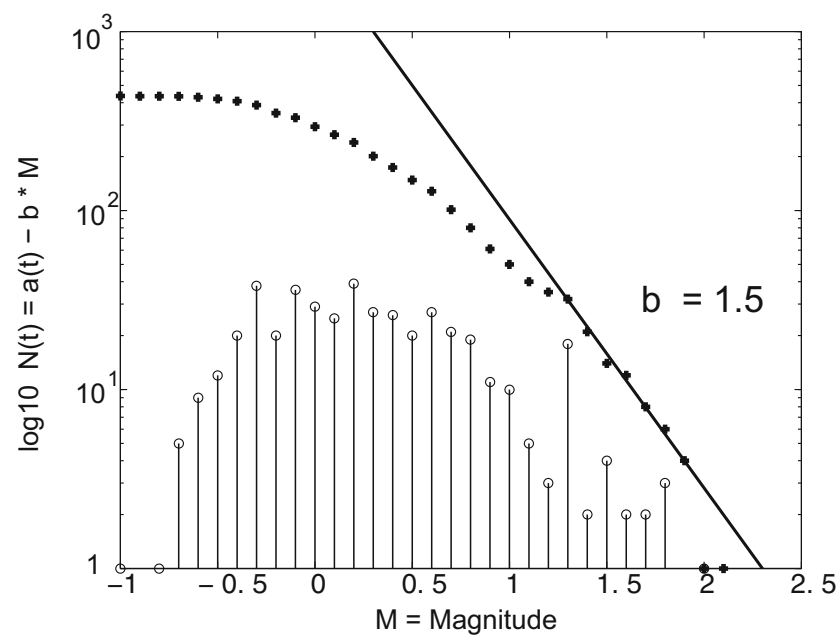

Fig. 6: The Gutenberg-Richter law of the 474 earthquakes of the Group A. $N(t)$ is the number of earthquakes of duration magnitude $\geq M_{d}$ during 117 days. The cumulative distribution is shown as closed diamonds and the noncumulative distribution as vertical lines with top open circles
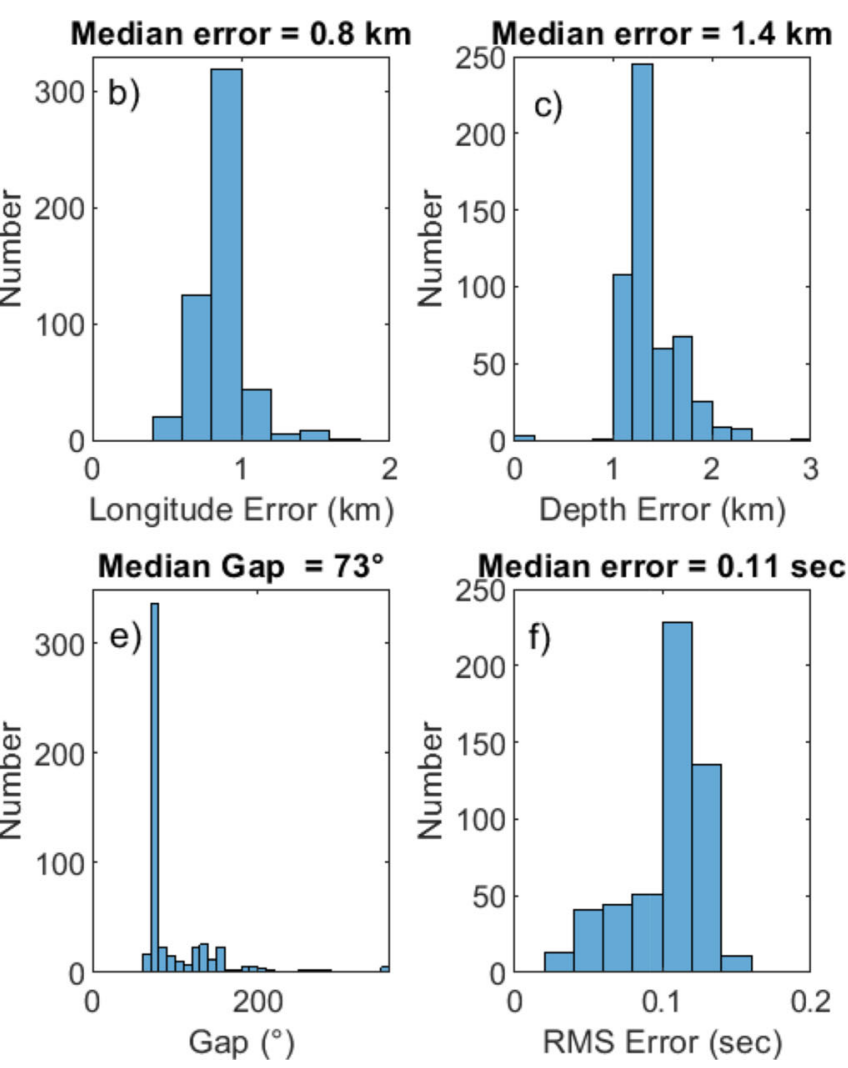

shows a normal focal mechanism with the $P$-axis subvertical and the T-axis in the NNW-SSW (350 $)$ direction (Fig. $7 \mathrm{~b}$ ). The average of the seismic moment tensor for Group $\mathrm{C}$ was not calculated because it had too few earthquakes (four focal mechanisms).

\section{Discussion}

\section{Spatial distribution and focal mechanisms of earthquakes}

The focal mechanisms of Group A are mainly strike-slip (Table 1 and Figs. 7 and 8). Their dips are high $\left(>60^{\circ}\right)$ and are compatible with the spatial distribution of the VTs of this group. For example, the dip of the two nodal planes of event one of Table 1 (the second largest event) is $66^{\circ}$ and $61^{\circ}$ depending of which of the two nodal planes is the fault plane and $78^{\circ}$ and $65^{\circ}$ for event four of Table 1 (the largest event). Whichever the fault plane is, the dips correspond to nearly vertical planes, in agreement with the in-depth steep distribution of the VTs (Fig. 4). Nevertheless, these dips do not allow selecting the actual fault plane among the two nodal planes because they are very similar (between about $60^{\circ}$ and $80^{\circ}$ ). Another way to select the fault plane among the two nodal planes is the use of the spatial distribution of epicenters of the VTs. Most of the earthquakes of Group A are distributed in an 
Fig. 7: (a) Focal mechanisms based on first-motion polarities and $\mathrm{S} / \mathrm{P}$ amplitude ratios. (b) Summations of the seismic moment tensors for Groups A and B, with their associated $\mathrm{P}$ and $\mathrm{T}$ axis. Red colors represent compression and the blue ones are associated to tension. The equivalent focal mechanisms are represented in black beachballs
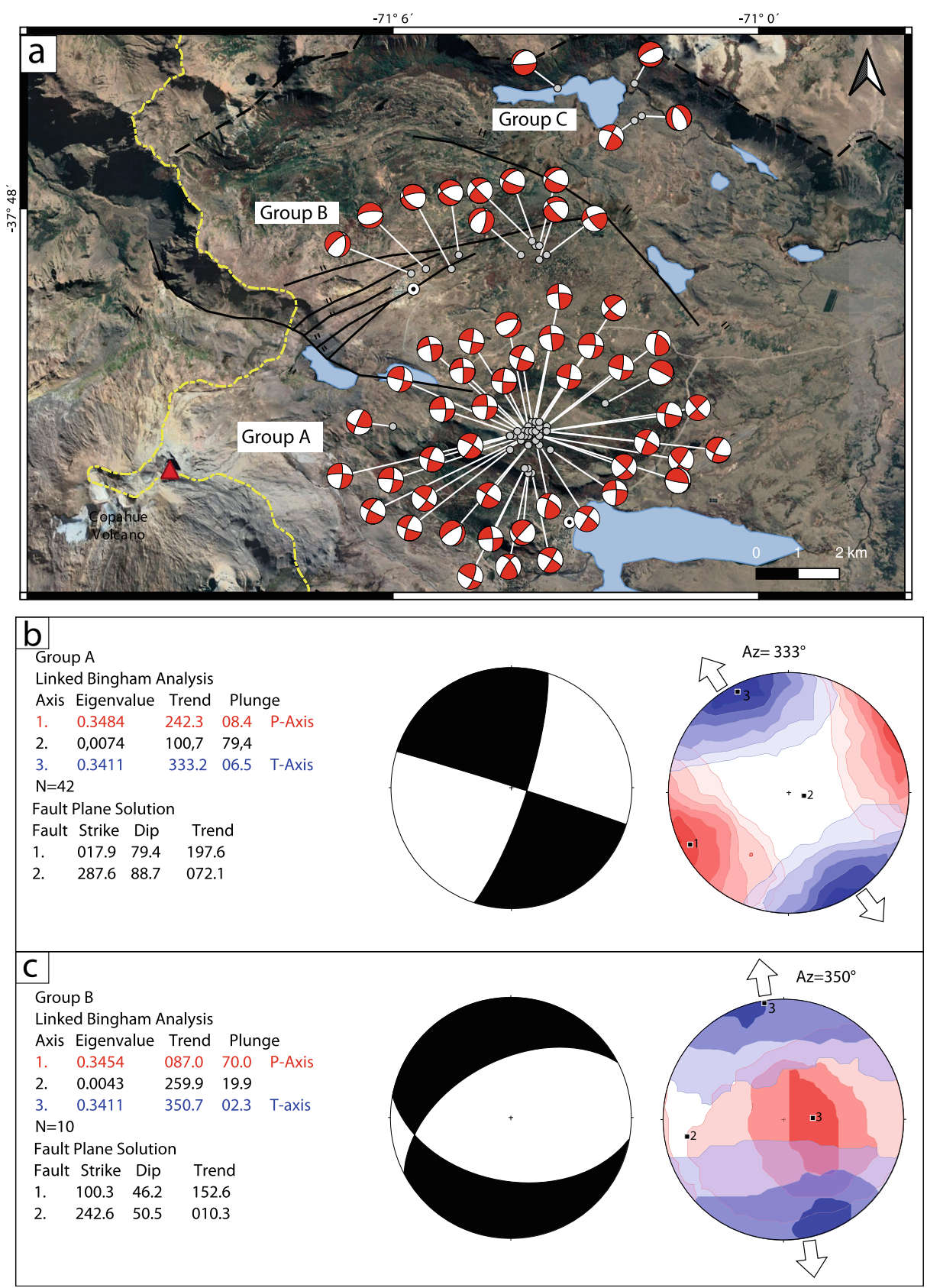

NNE direction. This NNE direction is therefore the most probable direction for the fault plane, considering that the location errors are small enough in such a way that the earthquakes cannot strike in the perpendicular EW direction. This implies that the events $3,4,5,11,15,19$, and 36 (Fig. 7 and Table 1) are right-lateral strike-slip mechanisms. This is in agreement with what suggested Bonali et al. (2016) for the faults close to Las Maquinas, and it is compatible with the right-lateral strike-slip mechanism of the LOFS. Hence, the influence of the LOFS reaches the region of Group A. We can therefore assume that the seismicity of Group A is the response of the regional stress field associated with the LOFS.
The spatial distribution of the epicenters of Group B has a $\sim \mathrm{N} 50^{\circ} \mathrm{E}$ strike direction (Fig. 4) and matches spatially with the direction of the faults close to Copahue village, known as the Copahue Village Fault System (CVFS). This direction is close to the strikes of several focal mechanisms (Table 1 and Fig. 7) of events of Group B earthquakes. Folguera and Ramos (2000) and Melnick et al. (2006) suggested that these faults are reverse due to a horsetail geometry associated with the Chancho-Co structure, defining a transpressional fault system. However, we found that the focal mechanisms of Group B are mainly normal, with a small right-lateral strike-slip component which is incompatible with their interpretation. Bonali 
a Group A

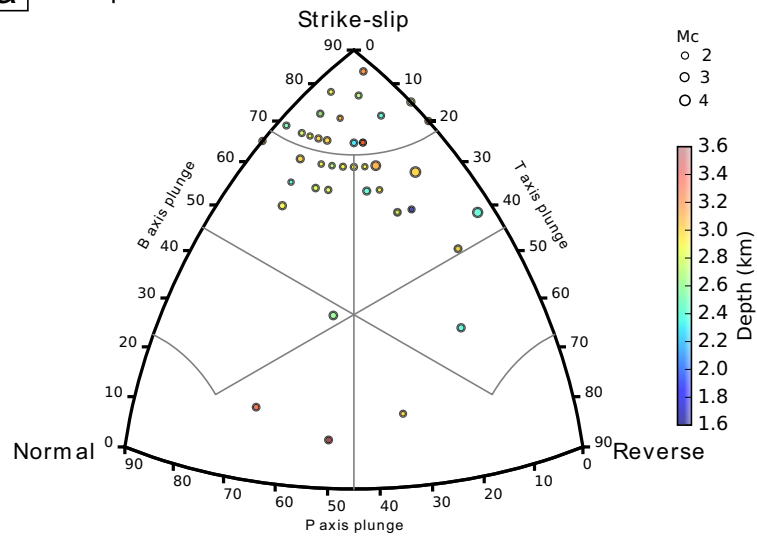

b Group B

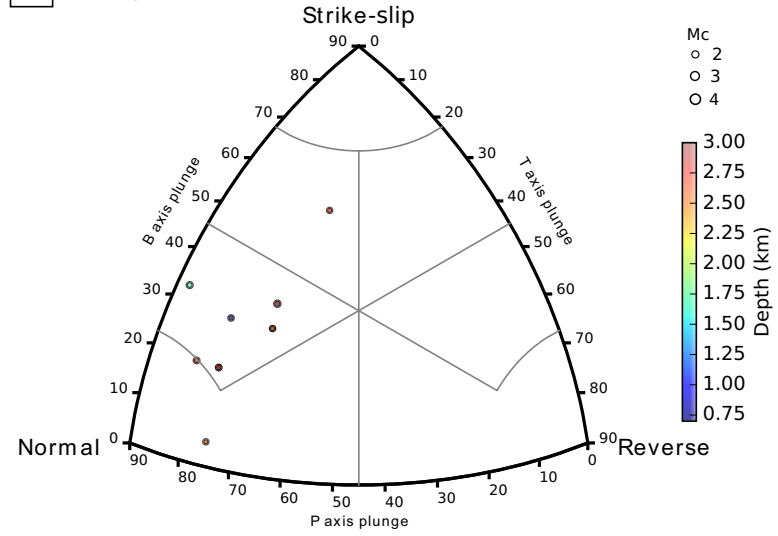

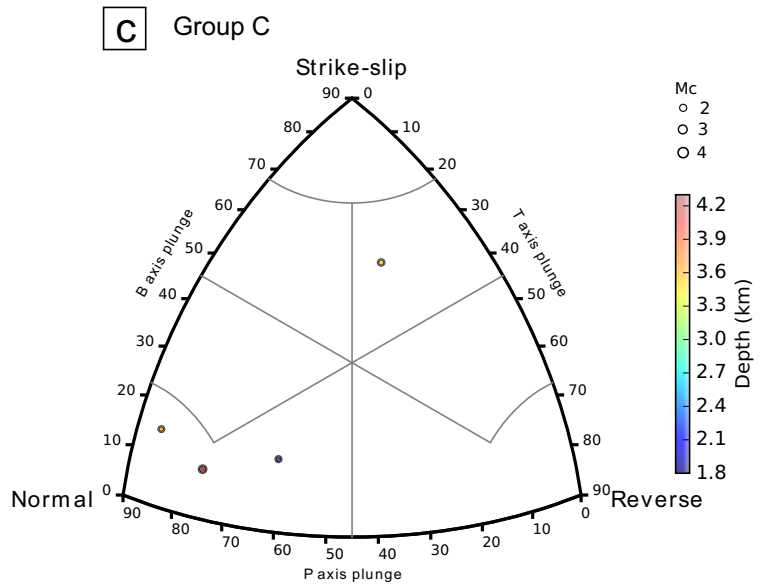

Fig. 8: Focal mechanism classification for (a) Group A, (b) Group B, (c) Group C. Diagrams were made with FMC (Álvarez-Gómez 2014)

et al. (2016) did not find any evidence of recent reverse faults, instead, these authors considered these structures as normal faults with a right-lateral strike-slip component. This is in agreement with our results and with Barcelona et al. (2019) and Lamberti et al. (2019) for the main structures at Anfiteatro, Termas de Copahue, and Maquinitas hydrotermal zones. The active Copahue volcano lies in the SW prolongation of these normal faults, in agreement with the tectonics of the Caviahue caldera.

The focal mechanisms of Group C consist of three normal and one strike-slip solutions. The strike-slip solution is very similar to that obtained for Group A, which could indicate that a fault system similar to Group A is also developing North of Trolope ranch, where Group $\mathrm{C}$ earthquakes are located. The normal fault plane solutions that we found are similar to the normal fault parallel to the northern caldera border, which is part of the Trolope graben (Melnick et al. 2006).

We want to compare the principal axis of the summation of the seismic moment tensor to the stress tensor calculated from the strikes and directions of striations observed on the fault plane of old faults by Barcelona et al. (2019). Even though we know that the directions of the $\mathrm{P}$ and $\mathrm{T}$ axis do not always coincide with the directions $\sigma_{1}$ and $\sigma_{3}$ of the principal axis of the stress tensor, it is almost the case for pure compressional or extensional regimes.
The NNW directions of the T-axes of Groups A and B are very similar and coincide with the direction of the minimum principal stress axis $\sigma_{3}$ calculated Barcelona et al. (2019) in Anfiteatro and Máquinitas. The subvertical P-axis of Group B is similar to the direction of the maximum principal stress axis $\sigma_{1}$ described by Barcelona et al. (2019). This is compatible with the normal faults of the nearby geothermal field (Group B), controlling the tectonics of this area (Barcelona et al. 2019). The $P$-axis of Group A, located southeast of Copahue village, is subhorizontal, revealing the strike-slip behavior of the end of the Liquiñe-Ofqui fault.

The selection of the fault planes among the two nodal planes mostly depends on the quality of earthquake locations, especially the epicenters. Given the small uncertainties in the hypocentral locations (Fig. 5), alternative solutions in which the aftershocks strike (for example) in the orthogonal WWNW direction are extremely unlikely. We conclude with high confidence that the aftershocks accommodated rightlateral slip along an NNE-striking vertical fault for Group A, and along an NE-striking normal mechanism for Group B.

\section{Origin of the seismicity}

The 2017-2018 seismicity is very shallow, of similar magnitudes, concentrated in space and time as clusters. The 
Fig. 9: Waveforms and associated spectrograms of the vertical component of the largest earthquake of December 6, 2017, $\mathrm{M}_{1}=3.4$. (a) Raw data, (b) filtered data between 5 and $10 \mathrm{~Hz}$, (c) filtered data between 10 and 49 $\mathrm{Hz}$ a)

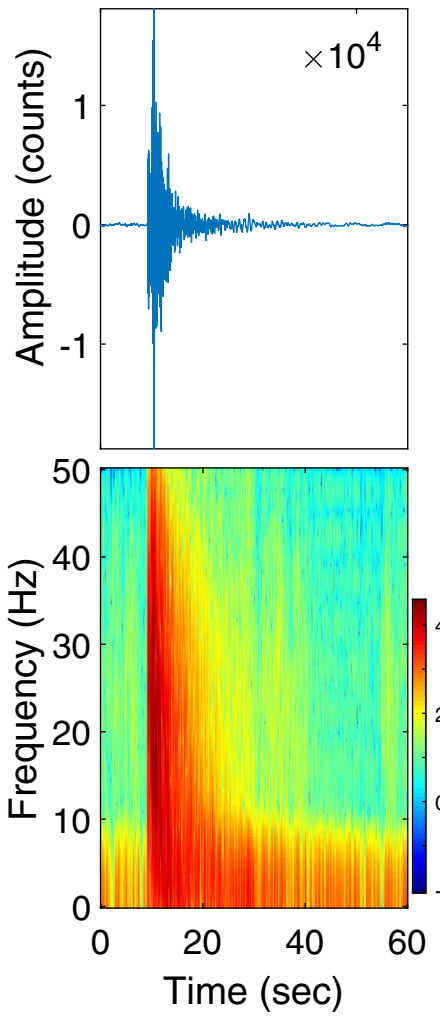

b)
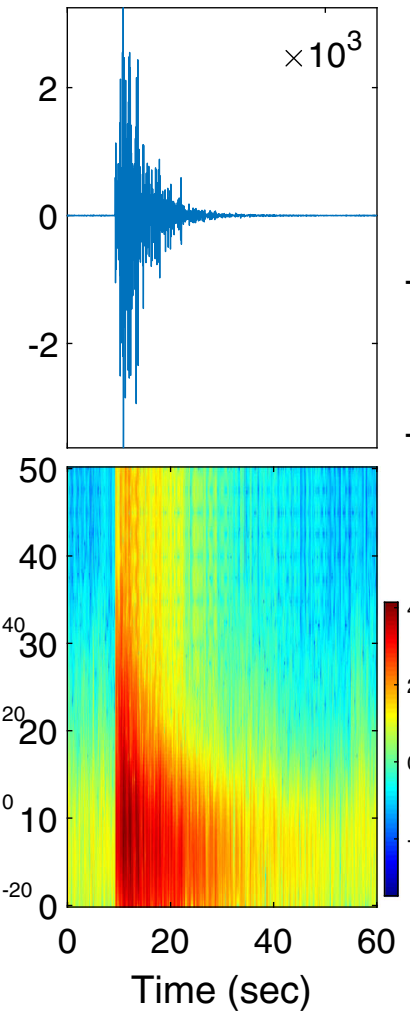

c)
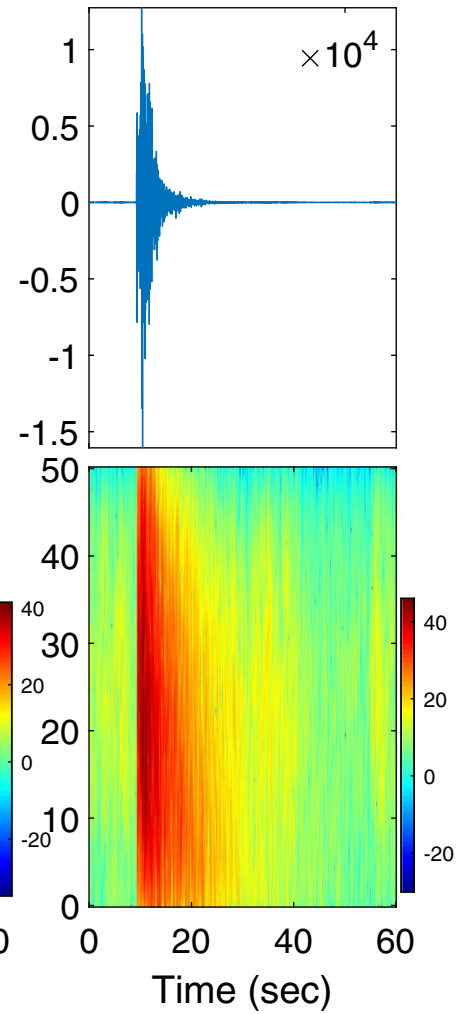

earthquake waveforms (Fig. 9) have a high frequency $(>5-10$ $\mathrm{Hz}$ ) content (due to both the small magnitudes and the short distance to the stations), suggesting very superficial events.

Their focal mechanisms and small depths are compatible with subsurface faults. The seismicity of Group A is located close to surface hydrothermal manifestations, with an associated $b$ value of $1.50 \pm 0.15$. Such high $b$ value can reflect the presence of fluids in volcanic and/or hydrothermal environments (Scholz 1968; Wyss 1973). The presence of hydrothermal fluids tends to reduce the effective normal stress, generating many small earthquakes more easily than without fluids, leading to high $b$ values (Scholz 1968; Wyss 1973). In our study, the seismicity is located close to the superficial hydrothermal regions, including hot springs, so a hydrothermal origin of the fluids is suspected. The high $b$ value may also reveal a highly heterogeneous medium, with numerous small faults where fluids can circulate more easily, as it is the case in the Caviahue caldera. Many of these faults reach the surface and have been studied by geologists (Figs. 1 and 4). This high $b$ value (1.5) is similar (up to 1.3 and 1.5) to the ones of Lazo et al. (2015) and Lundgren et al. (2017) calculated south of the Copahue fault zone. They also interpret them as reflecting fluid processes in the NE trending Copahue fault zone. We propose that this seismicity can be related to hydrothermalfluid circulations within a highly fractured, heterogeneous, and porous medium and not directly correlated with the volcanic activity and/or magma processes. The presence of magma may have an indirect influence, for example in the migration of hydrothermal fluids. The presence of water may also come from the Crater Lake which is mainly fed by fluids from a magma batch $\sim 4-5-\mathrm{km}$ deep (Varekamp 2004, Varekamp et al. 2006; Vélez et al. 2011). These crater-fluids are released by the constant fumaroles and degassing of the volcano, in addition to phreatic and phreato-magmatic explosions. Part of these fluids feeds the hydrothermal system and the acidic Caviahue Lake. Another possible origin of the high $b$ value is related to the shallow depths (less than $3.5 \mathrm{~km}$ ) of the seismicity. At shallow depths, a high degree of rock fracturing is present in this transition zone, and fluid-filled cracks, dykes, and fractures can be generated (McNutt 2005; Ibáñez et al. 2012; Legrand et al. 2012). Hence, the active tectonics control the circulation of hydrothermal fluids, and the presence of a high heterogeneous medium due to many small faults may generate our high $b$ value.

Fig. 9 shows an example of a VT recorded the December 6, 2017, at $02 \mathrm{~h}$ and $18 \mathrm{~min}$ UT. Fig. 9a shows the raw data with its spectrogram. As the earthquake is small $\left(M_{\mathrm{d}}=1.1\right)$ and is recorded at short distances (less than $10 \mathrm{~km}$ ), it has a high frequency content with frequencies until the Nyquist frequency of $50 \mathrm{~Hz}$. This VT has also low frequency content. We decomposed the signal into two frequency bands. One is between 5 and $10 \mathrm{~Hz}$ (Fig. 9b) that we call the low frequency content of the signal. This low frequency limit of $5 \mathrm{~Hz}$ has been chosen to remove the low frequency band related to the 
noise like the sea and appreciate better the duration of the low frequency content of the VT without been contaminated by the noise at these band frequencies. Nevertheless, the VT has also frequencies between 1 and $5 \mathrm{~Hz}$ (Fig. 9a). We can see these low frequencies last $30 \mathrm{~s}$ after the $\mathrm{P}$ wave arrival time, which is long for such small VT. The second frequency band is between 10 and $49 \mathrm{~Hz}$. This high frequency part lasts about 15-20 s after the $\mathrm{P}$ wave arrival time, as expected for a pure tectonic earthquake. This low frequency content is persistent during the entire seismic signal, even when the high frequency content has disappeared. The origin of these low frequencies may be double. A first possibility may be due to the presence of fluids in the medium. A second possibility may be due to the shallowness of the VTs (Wassermann 2011). In fact, both explanations are possible, and we have no real way to discriminate between them. The presence of fluids which remain in the aquifers can generate large hydrothermal explosions, like the one of March 25, 2018, which was registered and reported by OVDAS (2018), a few months after the 2017-2018 clusters. This explosion followed a sequence of 48 long-period events, probably related to the hydrothermal activity that occurred close to the Copahue volcano. These fluids can easily migrate within local shallow pre-existing faults and a heterogeneous medium because of the presence of many faults within the Caviahue caldera.

Hence, our interpretation of a hydrothermal origin of the seismicity of Group B is in agreement with what proposed Ibáñez et al. (2008); Lazo et al. (2015); Bonali et al. (2016); Lundgren et al. (2017); and Lamberti et al. (2019). For example, Lamberti et al. (2019) examined the link between faults, fractures, and diffuse degassing structures and suggested that the normal and strike-slip fault traces constitute the most favorable pathways for hydrothermal fluids and diffuse $\mathrm{CO}_{2}$. The region of study of these authors is an area situated northeast of the Copahue volcano, which, according to gravity and electrical resistivity surveys, represents a high conductivity zone of hot fluids circulation (JICA report 1992).

\section{VP/Vs value}

We found a $\mathrm{Vp} / \mathrm{Vs}$ value of 1.69 , smaller than the one expected for volcanoes, generally larger than 1.73 . The $\mathrm{Vp} / \mathrm{Vs}$ value was obtained for a very shallow region (the depths of the VTs are within the first kilometers of the crust). It may reflect a highly stressed region inside the pull-apart itself, a transition zone between the end of the right-lateral LOFS and the beginning of the thrust-fault Antiñir-Copahue Fault zone.

\section{Conclusion}

The location of 520 VTs of shallow depths (less than about 3.5 $\mathrm{km}$ ) that occurred in 2017-2018 within the Caviahue caldera, and the determination of their double-couple focal mechanisms allows splitting the seismicity into two clusters. One group (A), located northwest of Caviahue Lake, has a tectonic origin, with right-lateral strike slip faults in an NNE direction and may be the prolongation of the right-lateral strike-slip regional Liquiñe-Ofqui fault. The other group (B), located close to the geothermal fields and Copahue village, has a hydrothermal origin, with normal faults oriented in an NE direction. Hence, we confirmed that the Copahue Village Fault System, including the highly active geothermal field of Antiteatro and Las Maquinitas, is an active extensional normal fault zone with en échelon parallel normal faults that trend in an NE direction. The active Copahue volcano lies in the SW prolongation of these normal faults, in agreement with the tectonics of the caldera. These normal faults correspond to a transfer zone that joins the right-lateral strike-slip LOFS and the thrust-fault Antiñir Copahue Fault zone. Permanent observations of seismic clusters and/or swarms within the Caviahue caldera must be done in order to control their spatiotemporal evolution. Their origin can be tectonic, hydrothermal, or magmatic and should help in monitoring the active Copahue volcano in the future. A special care should be taken if the seismicity migrates towards the Copahue volcano. The low $\mathrm{Vp} / \mathrm{Vs}$ ratio reveals a highly stressed tectonic regime of a transition zone located between two different fault zones and shows that the tectonic regime is controlling the seismicity of the region.

Supplementary Information The online version contains supplementary material available at https://doi.org/10.1007/s00445-021-01442-7.

Acknowledgements We would like to thank all the colleagues and students who participated in the fieldwork and made it possible to carry out the seismological network. Adrian Arias, Higinio de Monte, and the municipality of Caviahue gave essential help during the installation and maintenance. This work was supported by the projects PI-UNRN 40-A548, PICT-2016-0269, and the financial aid of the department of Earth Sciences from University of Florence. DL thanks PASPA-DGAPA, UNAM program for a sabbatical year in Florence, Italy, where this study started. We thank Jesús Ibáñez, an anonymous reviewer, and the editor for constructive comments on the article.

\section{References}

Adriasola A, Thomson S, Brix M, Hervé F, Stöckhert B (2006) Postmagmatic cooling and late Cenozoic denudation of the North Patagonian Batholith in the Los Lagos region of Chile, $41^{\circ}-42^{\circ}$ 15' S. Int J Earth Sci 95:504-528. https://doi.org/10.1007/s00531005-0027-9

Agurto H, Rietbrock A, Barrientos S, Bataille K, Legrand D (2012) Seismo-tectonic structure of the Aysén Region, Southern Chile, inferred from the $2007 M_{\mathrm{w}}=6.2$ Aysén earthquake sequence. Geophys J Int 190(1):116-130

Agusto M, Tassi F, Caselli A, Vaselli O, Tedesco D, Poreda R (2007) Chemical and isotopic features of thermal fluid discharges in the volcano-hydrothermal system of Caviahue-Copahue volcanic complex (Argentina), in: Geosur 2007: An International Congress on the 
Geology and Geophysics of the Southern Hemisphere. Santiago de Chile, Actas, p 9

Aki K (1965) Maximum likelihood estimate of $b$ in the formula $\log (N)=$ a-bM and its confidence limits. Bull Earthquake Res Inst Tokyo Univ 43:237-239

Allmendinger R, Cardozo N, Fisher D (2011) Structural geology algorithms: vectors and tensors. Cambridge University Press

Álvarez-Gómez J (2014) FMC: a one-liner python program to manage, classify and plot focal mechanisms, in: EGU General Assembly Conference Abstracts

Amato A, Chiarabba C, Cocco M, di Bona M, Selvaggi G (1994) The 1989-1990 seismic swarm in the Alban Hills volcanic area, central Italy. J Volcanol Geotherm Res 61:225-237

Angermann D, Klotz J, Reigber C (1999) Space-geodetic estimation of the Nazca-South America Euler vector. Earth Planet Sci Lett 171: 329-334

Aoki Y, Segall P, Kato T, Cervelli P, Shimada S (1999) Imaging magma transport during the 1997 seismic swarm off the Izu Peninsula, Japan. Science 286:927-930

Barcelona H, Yagupsky D, Vigide N, Senger M (2019) Structural model and slip-dilation tendency analysis at the Copahue geothermal system: inferences on the reservoir geometry. J Volcanol Geotherm Res 375:18-31

Barrientos S, Ward S (1990) The 1960 Chile earthquake: inversion for slip distribution from surface deformation. Geophys J Int 103:589 598. https://doi.org/10.1111/j.1365-246X.1990.tb05673.x

Bonali F (2013) Earthquake-induced static stress change on magma pathway in promoting the 2012 Copahue eruption. Tectonophysics 608 : $127-137$

Bonali F, Corazzato C, Bellotti F, Groppelli G (2016) Active tectonics and its interactions with Copahue volcano, in: Copahue volcano. Springer, pp. 23-45

Caselli A, Agusto M, Vélez M, Forte P, Bengoa C, Daga R, Albite J, Capaccioni B (2016) The 2012 eruption. In: Copahue volcano. Springer, Berlin, pp 61-77

Cembrano J, Lara L (2009) The link between volcanism and tectonics in the southern volcanic zone of the Chilean Andes: a review. Tectonophysics 471:96-113

Cembrano J, Hervé F, Lavenu A (1996) The Liquiñe-Ofqui fault zone: a long-lived intra-arc fault system in southern Chile. Tectonophysics 259:55-66. https://doi.org/10.1016/0040-1951(95)00066-6

Cembrano J, Lavenu A, Reynolds P, Arancibia G, López G, Sanhueza A (2002) Late Cenozoic transpressional ductile deformation north of the Nazca-South America-Antarctica triple junction. Tectonophysics 354:289-314

Chinn D, Isacks B (1983) Accurate source depths and focal mechanisms of shallow earthquakes in western South America and in the New Hebrides island arc. Tectonics 2:529-563

Chouet B (1996) Long-period volcano seismicity: its source and use in eruption forecasting. Nature 380:309-316

Chouet B, Matoza R (2013) A multi-decadal view of seismic methods for detecting precursors of magma movement and eruption. J Volcanol Geotherm Res 252:108-175

Cox S (2005) Coupling between deformation, fluid pressures, and fluid flow in oreproducing hydrothermal systems at depth in the crust. Economic Geology 100th Anniversary Volume:39-75

DeMets C, Gordon R, Argus D, Stein S (1994) Effect of recent revisions to the geomagnetic reversal time scale on estimates of current plate motions. Geophys Res Lett 21:2191-2194

Díaz D, Zúñiga F, Castruccio A (2020) The interaction between active crustal faults and volcanism: a case study of the Liquiñe-Ofqui Fault Zone and Osorno volcano. Southern Andes, using magnetotellurics, JVGR 393:106806

Endo E, Malone S, Noson L, Weaver C (1981) Locations magnitudes and statistics of the March 20-May 18 earthquake sequence. U.S. Geol.
Surv. Prof. Pap. 1250, 93-107 US Govt. Printing Office, Washington, DC

Folguera A, Ramos V (2000) Control estructural del volcán Copahue: implicancias tectónicas para el arco volcánico cuaternario $\left(36^{\circ}\right.$ $\left.39^{\circ} \mathrm{S}\right)$. Rev Asoc Geol Argent 55:229-244

Folguera A, Ramos V, Melnick D (2002) Partición de la deformación en la zona del arco volcánico de los Andes neuquinos (36-39 $\left.{ }^{\circ} \mathrm{S}\right)$ en los últimos 30 millones de años. Revista Geológica de Chile 29, $227-$ 240

Folguera A, Ramos V, Hermanns R, Naranjo J (2004) Neotectonics in the foothills of the southernmost central Andes (37-38 S): Evidence of strike-slip displacement along the Antiñir-Copahue fault zone. Tectonics 23

Folguera A, Rojas Vera E, Vélez L, Tobal J, Orts D, Agusto M, Caselli A, Ramos V (2016) A review of the geology, structural controls, and tectonic setting of Copahue volcano, southern volcanic zone, Andes, Argentina. Springer Berlin Heidelberg, Berlin, Heidelberg, pp 3-22. https://doi.org/10.1007/978-3-662-48005-2_1

Forte P, Bengoa C, Caselli A (2012) Análisis preliminar de la actividad sísmica del complejo volcánico Copahue-Caviahue mediante técnicas de array, in: XIII Congreso Geológico Chileno, Antofagasta, pp. 574-576

Gudmundsson A (2011) Rock fractures in geologic processes. In: Rock Fractures in Geological Processes. https://doi.org/10.1017/ CBO9780511975684

Hardebeck J, Shearer P (2003) Using S/P amplitude ratios to constrain the focal mechanisms of small earthquakes. Bull Seismol Soc Am 93: 2434-2444

Havskov J, Voss P, Ottemöller L (2020) Seismological observatory software: 30 yr of SEISAN. Seismological Research Letters 91(3): 1846-1852. https://doi.org/10.1785/0220190313

Hildreth W, Moorbath S (1988) Crustal contributions to arc magmatism in the Andes of central Chile. Contrib Mineral Petrol 98:455-489

Hill D (1977) A model for earthquake swarms. J Geophys Res 82:13471352

Hill D, Ellsworth W, Johnston M, Langbein J, Oppenheimer D, Pitt A, Reasenberg P, Sorey M, McNutt S (1990) The 1989 earthquake swarm beneath Mammoth Mountain, California: an initial look at the 4 May through 30 September activity. Bull Seismol Soc Am 80: 325-339

Hurst A, McGinty P (1999) Earthquake swarms to the west of Mt Ruapehu preceding its 1995 eruption. J Volcanol Geotherm Res 90:19-28

Ibáñez J, Del Pezzo E, Almendros J, La Rocca M, Alguacil G, Ortiz R, García A (2000) Seismo volcanic signals at Deception Island volcano (Antarctica): wavefield analysis and source modeling. J Geophys Res 105(6):13905-13931

Ibáñez J, Carmona E, Almendros J, Saccorotti G, Del Pezzo E, Abril M, Ortiz R (2003) The 1998-1999 seismic series at Deception Island volcano, Antarctica. J Vol Geo Res 128:65-88

Ibáñez J, Del Pezzo E, Bengoa C, Caselli A, Badi G, Almendros J (2008) Volcanic tremor and local earthquakes at Copahue volcanic complex, Southern Andes, Argentina. J Volcanol Geotherm Res 174: 284-294

Ibáñez J, De Angelis S, Díaz-Moreno A, Hernández P, Alguacil G, Posadas A, Pérez N (2012) Insights into the 2011-2012 submarine eruption off the coast of El Hierro (Canary Islands, Spain) from statistical analyses of earthquake activity. Geophys J Int 191:659670

JICA report (1992) The feasibility study on the Northern Neuquén Geothermal Development Project. Final Report. Japan International Cooperation Agency

Kanamori H, Rivera L (2017) An $M_{\mathrm{w}}=7.7$ slow earthquake in 1960 near the Aysén Fjord region, Chile. Geophysical Journal International 211. https://doi.org/10.1093/GJ//GGX292 
Kundu B, Legrand D, Gahalaut K, Gahalaut V, Mahesh P, Kamesh Raju K, Catherine J, Ambikapthy A, Chadha R (2012) The 2005 volcanotectonic earthquake swarm in the Andaman Sea: triggered by the 2004 great Sumatra-Andaman earthquake. Tectonics 31:TC5009. https://doi.org/10.1029/2012TC003138

Lamberti M, Vigide N, Venturi S, Agusto M, Yagupsky D, Winocur D, Tassi F (2019) Structural architecture releasing deep-sourced carbon dioxide diffuse degassing at the Caviahue-Copahue volcanic complex. J Volcanol Geotherm Res 374:131-141

Lange D, Cembrano J, Rietbrock A, Haberland C, Dahm T, Bataille K (2008) First seismic record for intra-arc strike-slip tectonics along the Liquiñe-Ofqui fault zone at the obliquely convergent plate margin of the southern Andes. Tectonophysics 455:14-24. https://doi. org/10.1016/j.tecto.2008.04.014

Lavenu A, Cembrano J (1999) Compressional and transpressional-stress pattern for Pliocene and Quaternary brittle deformation in fore arc and intra-arc zones (Andes of central and southern Chile). J Struct Geol 21:1669-1691. https://doi.org/10.1016/S0191-8141(99) 00111-X

Lazo J, Basualto D, Bengoa C, Cardona C, Franco L, Gil-Cruz F, Morales S (2015) Spatial distribution of b-value of the Copahue volcano during 2012-2014 eruptive period: relationship between magmatic and hydrothermal system. EGUGA 982

Lee W, Bennet R, Meaghu K (1972) A method of estimating magnitude of local earthquakes from signal duration. U.S. Geological Survey Open File Report, 28 pp.

Legrand D, Calahorrano A, Guillier B, Rivera L, Ruiz M, Villagómez D, Yepes H (2002) Stress tensor analysis of the 1998-1999 tectonic swarm of northern Quito related to the volcanic swarm of Guagua Pichincha volcano, Ecuador. Tectonophysics 344(1):15-36

Legrand D, Baby P, Bondoux F, Dorbath C, Bes de Berc S, Rivadeneira M (2005) The 1999-2000 seismic experiment of Macas swarm (Ecuador) in relation with rift inversion in Subandean foothills. Tectonophysics 395:67-80

Legrand D, Barrientos S, Bataille K, Cembrano J, Pavez A (2011) The fluid-driven tectonic swarm of Aysen Fjord, Chile (2007) associated with two earthquakes $\left(M_{\mathrm{w}}=6.1\right.$ and $\left.M_{\mathrm{w}}=6.2\right)$ within the LiquiñeOfqui fault zone. Cont Shelf Res 31:154-161

Legrand D, Tassara A, Morales D (2012) Megathrust asperities and clusters of slab dehydration identified by spatiotemporal characterization of seismicity below the Andean margin. Geophys J Int 191:923-931

Legrand D, Marroquín G, DeMets C, Mixco L, García A, Villalobos M, Ferrés D, Gutíerrez E, Escobar D, Torres R, Hernández D (2020) Active deformation in the San Salvador extensional stepover, El Salvador from an analysis of the April-May 2017 earthquake sequence and GPS data. J South Am Eart Sc 104:102854

Legrand D, Iglesias A, Singh S, Cruz-Atienza V, Yoon C, Dominguez LA, Valenzuela R, Suárez G, Castro-Artola O (2021) The influence of fluids in the unusually high-rate seismicity in the Ometepec segment of the Mexican subduction zone. Geophys J Int accepted

Lesage P, Heap M, Kushnir A (2018) A generic model for the shallow velocity structure of volcanoes. J Volcanol Geotherm Res 356:114 126. https://doi.org/10.1016/j.jvolgeores.2018.03.003

Linares E, Ostera H, Mas L (1999) Cronologia potasio-argon del complejo efusivo Copahue-Caviahue, Provincia del Neuquen. Rev Asoc Geol Argent 54:240-247

Lundgren P, Nikkhoo M, Samsonov S, Milillo P, Gil-Cruz F, Lazo J (2017) Source model for the Copahue volcano magma plumbing system constrained by InSAR surface deformation observations. J Geophys Res Solid Earth 122(7):5729-5747

Malone S, Pavlis G (1983) Velocity structure and relocation of earthquakes at Mount St. Helens Eos Trans AGU 64:895

McNutt S (1996) Seismic monitoring and eruption forecasting of volcanoes: a review of the state-of-the-art and case histories. In: Scarpa R, Tilling R (eds) Monitoring and mitigation of volcano hazards. Springer-Verlag, pp 99-146
McNutt S (2005) Volcanic seismology. Annu Rev Earth Planet Sci 32: 461-491

Melnick D, Folguera A, Ramos V (2006) Structural control on arc volcanism: the Caviahue-Copahue complex, Central to Patagonian Andes transition ( $38^{\circ} \mathrm{S}$ ). J S Am Earth Sci 22(66):88-88. https:// doi.org/10.1016/j.jsames.2006.08.008

Mogi K (1963) Some discussions on the aftershocks, foreshocks and earthquake swarms - the fracture of a semi-infinite body caused by an inner stress origin and its relation to the earthquake phenomena. Bull Earthq Res Inst, Univ Tokyo 41:615-658

Mora-Stock C, Comte D, RussoR GA, Mocanu V (2010) Aysén seismic swarm (January 2007) in southern Chile: analysis using joint hypocentral determination. J Seismol 14(4):683-691. https://doi.org/10. 1007/s10950-010-9190-y

OVDAS, Observatorio Volcanológico de los Andes del Sur (2018) Reporte especial de actividad volcánica Región del Bio Bio, 26 de Marzo de 2018, 16:30 horas (Horario Local). Retrieved from http:// sitiohistorico.sernageomin.cl/reportes Volcanes/ 20180326044953227REAV_20180326_1630_Copahue.pdf

Patanè D, De Gori P, Chiarabba C, Bonaccorso A (2003) Magma ascent and the pressurization of Mount Etna's volcanic system. Science 299(5615):2061-2063

Pavlis G, Booker J (1983) Progressive multiple event location (PMEL). Bull Seismol Soc Am 73:1753-1777

Pérez-Estay N, Yáñez G, Crempien J, Roquer T, Cembrano J, Valdenegro P, Aravena D, Arancibia G, Morata D (2020) Seismicity in a transpressional volcanic arc: the Liquiñe-Ofqui fault system in the Puyuhuapi area, Southern Andes, Chile $\left(44^{\circ} \mathrm{S}\right)$. Tectonics. 39. https://doi.org/10.1029/2020TC006391

Pesce A (1989) Evolución volcano-tectónica del complejo efusivo Copahue-Caviahue y su modelo geotérmico preliminar. Rev Asoc Geol Argent 44:307-327

Power J, Lahr J, Page R, Chouet B, Stephens C, Harlow D, Murray T, Davies J (1994) Seismic evolution of the 1989-1990 eruption sequence of Redoubt volcano. Alaska J Volcanol Geotherm Res 62: 69-94

Radic J (2010) Las cuencas cenozoicas y su control en el volcanismo de los Complejos Nevados de Chillán y Copahue-Callaqui (Andes del Sur, 36-39 S). Andean Geol 37:220-246

Rojas Vera E, Folguera A, Spagnuolo M, Giménez M, Ruiz F, Martinez P, Ramos V (2009) La neotectónica del arco volcánico a la latitud del volcán Copahue $\left(38^{\circ} \mathrm{S}\right)$. Andes de Neuquén Revista de la Asociación Geológica Argentina 65(204):214

Roman D, Power J, Moran S, Cashman K, Doukas M, Neal C, Gerlach T (2004) Evidence for dike emplacement beneath Iliamna volcano, Alaska in 1996. J Volcanol Geotherm Res 130:265-284

Rosenau M (2004) Tectonics of the Southern Andean intra-arc zone ( $38^{\circ}$ $\left.42^{\circ} \mathrm{S}\right)$. Ph.D. thesis. Free University, Berlin, Germany

Rosenau M, Melnick D, Echtler H (2006) Kinematic constraints on intraarc shear and strain partitioning in the southern Andes between $38^{\circ}$ $\mathrm{S}$ and $42^{\circ} \mathrm{S}$ latitude. Tectonics 25

Russo R, Gallego A, Comte D, Mocanu V, Murdie R, Mora C, VanDecar $\mathrm{J}$ (2011) Triggered seismic activity in the Liquiñe-Ofqui fault zone, southern Chile, during the 2007 Aysen seismic swarm. Geophys J Int 184(3):1317-1326. https://doi.org/10.1111/j.1365-246X.2010. 04908.x

Scholz C (1968) The frequency-magnitude relation of microfracturing in rock and its relation to earthquakes. Bull Seismol Soc Am 58:399 415

Sielfeld G, Lange D, Cembrano J (2019) Intra-arc crustal seismicity: seismo-tectonic Implications for the southern Andes volcanic zone, Chile. Tectonics. https://doi.org/10.1029/2018TC004985

Snoke J (1984) A program for focal mechanism determination by combined use of polarity and SVP amplitude ratio data. Earthq Notes 55: 15 
Stern C (2004) Active Andean volcanism: its geologic and tectonic setting. Revista geológica de Chile 31:161-206

Tamburello G, Agusto M, Caselli A, Tassi F, Vaselli O, Calabrese S, Rouwet D, Capaccioni B, Di Napoli R, Cardellini C et al (2015) Intense magmatic degassing through the lake of Copahue volcano, 2013-2014. J Geophys Res Solid Earth 120:6071-6084

Toda S, Stein R, Sagiya T (2002) Evidence from the AD 2000 Izu islands earthquake swarm that stressing rate governs seismicity. Nature 419(6902):58-61

Varekamp J (2004) Copahue volcano: a modern terrestrial analog for the opportunity landing site? EOS Trans Am Geophys Union 85(41): 401-407

Varekamp J, Ouimette A, Herman S, Bermúdez A, Delpino D (2001) Hydrothermal element fluxes from Copahue, Argentina: a "beehive" volcano in turmoil. Geology 29:1059-1062

Varekamp J, deMoor J, Merrill M, Colvin A, Goss A, Vroon P, Hilton D (2006) Geochemistry and isotopic characteristics of the CaviahueCopahue volcanic complex, Province of Neuquén, Argentina. SPECIAL PAPERS-GEOLOGICAL SOCIETY OF AMERICA 407:317

Vargas G, Rebolledo S, Sepulveda S, Lahsen A, Thiele R, Townley B et al (2013) Submarine earthquake rupture, active faulting and volcanism along the major Liquiñe-Ofqui Fault Zone and implications for seismic hazard assessment in the Patagonian Andes. Andean Geology 40:141-171
Vélez M, Euillades P, Caselli A, Blanco M, Díaz J (2011) Deformation of Copahue volcano: inversion of InSAR data using a genetic algorithm. J Volcanol Geotherm Res 202:117-126

Waldhauser F, Ellsworth W (2000) A double-difference earthquake location algorithm: method and application to the northern Hayward fault, California. Bull Seismol Soc Am 90:1353-1368

Walter T, Wang R, Zimmer M, Grosser H, Lühr B, Ratdomopurbo A (2007) Volcanic activity influenced by tectonic earthquakes: static and dynamic stress triggering at Mt. Merapi. Geophys Res Lett 34: L05304. https://doi.org/10.1029/2006GL028710

Wassermann J (2011) Volcano Seismology, Chapter 13, IASPEI New manual of seismological observatory practice 2, NMSOP-2. https:// doi.org/10.2312/GFZ.NMSOP.2 ch13

Watt SF, Pyle DM, Mather TA (2009) The influence of great earthquakes on volcanic eruption rate along the Chilean subduction zone. Earth Planet Sci Lett 277:399-407. https://doi.org/10.1016/j.epsl.2008.11. 005

White R, McCausland W (2016) Volcano-tectonic earthquakes: a newtool for estimating intrusive volumes and forecasting eruptions. J Volcanol Geotherm Res 309:139-155

White R, McCausland W (2019) A process-based model of pre-eruption seismicity patterns and its use for eruption forecasting at dormant stratovolcanoes. J Volcanol Geotherm Res 382:267-297

Wyss M (1973) Towards a physical understanding of the earthquake frequency distribution. Geophys J R Astron Soc 31:341-359 